\title{
不活性型レニン分泌に対する顎下腺の意義： ラット腎皮質スライスを用いた研究
}

\author{
岐阜大学医学部第3内科 \\ 五井麗司, 宮崎青爾, 坂 中 昭 典 \\ 百々修二, 地 守研三, 三 浦 清 \\ Release Mechanisms of Inactive Renin from Rat Renal \\ Cortical Slices: Role of the Submandibular Gland \\ Reiji GOI, Seiji MIYAZAKI, Akinori SAKANAKA, \\ Shuji DODO, Kenzo CHIMORI and Kiyoshi MIURA
}

The Third Department of Internal Medicine, Gifu University School of Medicine, Gifu 500, Japan

In our previous studies, we showed an in vivo stimulating effect of the extract of the rat submandibular gland on plasma inactive renin release. In this study, we evaluated the effects of the rat submandibular gland extract and of some plasma active renin stimulants on inactive renin release from rat renal cortical slices.

Adult male Wistar rats $(250-350 \mathrm{~g})$ were kept on a regular diet $(\mathrm{Na} 260 \mathrm{mg} / 100 \mathrm{~g})$ and nephrectomized under pentobarbital anesthesia $(50 \mathrm{mg} / \mathrm{kg}$, i.p.). Five thin renal cortical slices were obtained from each kidney by using a razor blade. These renal cortical slices were incubated in Earle's buffer ( $\mathrm{pH} 7.4$, Difco) at $37^{\circ} \mathrm{C}$ for $30 \mathrm{~min}$ (preincubation), then transferred into $10 \mathrm{ml}$ fresh Earle's buffer with or without some agents and incubated at $37^{\circ} \mathrm{C}$ for 1 hour (experimental incubation). For each experiment, 6 groups of 5 renal cortical slices were employed. The agents used in this study were as follows: isoproterenol $\left(10^{-5} \mathrm{M}\right)$, furosemide $(50 \mu \mathrm{g} / \mathrm{ml})$, prostaglandin $\mathrm{E}_{1}\left(10^{-5} \mathrm{M}\right)$, prostaglandin $\mathrm{I}_{2}\left(10^{-5} \mathrm{M}\right)$ and the rat submandibular gland extract $(100 \mu \mathrm{l})$ which was obtained after homogenation with $10 \times(\mathrm{w} / \mathrm{v}) 0.01 \mathrm{M}$ pyrophosphate buffer $(\mathrm{pH} 6.5)$ including $0.1 \mathrm{M} \mathrm{NaCl}$. One $\mathrm{ml}$ of samples of this Earle's buffer were withdrawn every 20min. Active renin in the samples was assayed by the commercial RIA-kit (Dainabot), and total renin was assayed after trypsin (Worthington) treatment $\left(30 \mu \mathrm{g} / 300 \mu \mathrm{l}\right.$ sample) at $4^{\circ} \mathrm{C}$ for $10 \mathrm{~min}$. Inactive renin was determined as the difference between total renin and active renin.

Active and inactive renins increased linearly in the buffer without any agents (control) during the observation period $(60 \mathrm{~min})$. Isoproterenol $\left(10^{-5} \mathrm{M}\right)$ stimulated the release of active renin significantly $(\mathrm{p}<0.01 \mathrm{vs}$. control) but did not affect the release of inactive renin. Furosemide $(50 \mu \mathrm{g} / \mathrm{ml})$ stimulated the release of active and inactive renins 
significantly at 20 and $40 \mathrm{~min}$ ( $\mathrm{p}<0.05$ vs. control) but did not affect the release of either renin at $60 \mathrm{~min}$. Both prostaglandins $\mathrm{E}_{1}$ and $\mathrm{I}_{2}\left(10^{-5} \mathrm{M}\right)$ stimulated the release of active renin significantly $(\mathrm{p}<0.01 \mathrm{vs}$. control) but inhibited, on the other hand, the release of inactive renin significantly $(\mathrm{p}<0.01 \mathrm{vs}$. control). The rat submandibular gland extract $(100 \mu \mathrm{l})$ did not affect the release of active renin but stimulated the release of inactive renin significantly $(\mathrm{p}<0.05$ vs. control).

From these results, the findings can be summarized as follows:

1) As far as isoproterenol, furosemide, prostaglandins $E_{1}$ and $I_{2}$, and the rat submandibular gland extract were concerned, no agents stimulated or inhibited the release of either active or inactive renin at the same time from rat renal cortical slices. This may suggest that the release mechanisms of both renins may be different.

2) It is suggested that some materials in the rat submandibular gland and prostaglandins $E_{1}$ and $I_{2}$ participate in the release of inactive renin, the rat submandibular gland may be responsible for the stimulatory mechanism of inactive renin release, and prostaglandins $E_{1}$ and $\mathrm{I}_{2}$ may be responsible for the inhibitory mechanism.

\section{緒言}

血漿活性型レニン（PAR）は，主として腎の傍系球体細胞より分泌され，腎血管内の圧受容体， macula densa, 交感神経系, 更には, アンギオテンシンIIやプロスタグランジン等のホルモンな どによりその分泌をコントロールされている25)。しかし，血漿不活性型レニン（PIR）については， ヒトやラットを含む動物においてその存在が認められてはいるが，その産生部位や分泌機序につい てはいまだ不明である ${ }^{2123)}$ 。我々は, 両側の腎臓を摘出したラットでは, PAR の著減と PIR の 增加が認められたが, 両側の腎臓と同時に頻下腺を摘出したラットでは, 腎摘後の PAR の著減 は認められたが, 腎摘後の PIR の増加が阻止された事を報告し, 腎摘後の PIR の増加に買下腺 が関係している事を示した ${ }^{11200}$ 。従来より，腎臓からの活性型レニン分泌に対する薬物の影響の検

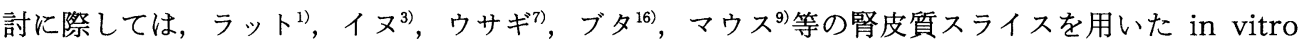
の実験が行われて来た。この方法を用いれば, 圧受容体と交感神経系の影響は除外され, 傍系球体 細胞に対する薬物の直接的な影響を調べる事ができる。我々は, 本研究の予備実験で, ラットの腎 皮質スライスからは, 活性型レニンのみならず, 活性型レニンの数倍にも達する不活性型レニンも 分泌される事を確認した。そこで, 不活性型レニンの分泌機序を解明する為に, in vivo で活性型 レニン分泌を刺激する事が知られている各種薬物を用いて，これらの，ラットの腎皮質スライスか らの活性型扔よび不活性型レニン分泌に対する影響を検討した。薬物としては，L-イソプロテレ ノール, フロセマイド, プロスタグランジン $\mathrm{E}_{1}$ 及び $\mathrm{I}_{2}$ を使用した。更に, 以前の我々の研究か ら不活性型レニン分泌との強い関係が示唆されたラットの買下腺中に, 不活性型レニン分泌に関与 する因子があるかどらかを調べる目的で, 買下腺の粗抽出液を作成し, 前記薬物と同様な検討を行っ た。 


\section{材 料 と方 法}

\section{A）腎皮質スライスの作製}

実験動物として，250-350g の雄ウイスターラット（中部科学資材株式会社）を使用し，ラット は普通食 ( $\mathrm{Na} 260 \mathrm{mg} / 100 \mathrm{~g}$, 日本クレア株式会社) で飼育した。腎皮質スライスのインキュベー ションには, TC MEDIUM EAGLE EARLE BSS ( $\mathrm{NaCl}: 116 \mathrm{mM}, \mathrm{KCl}: 5.4 \mathrm{mM}, \mathrm{CaCl}_{2}: 1.8$ $\mathrm{mM}, \mathrm{MgSO}_{4}: 0.8 \mathrm{mM}, \mathrm{NaH}_{2} \mathrm{PO}_{4}: 1.0 \mathrm{mM}$, Difco）（以下 Earle バッファーと略す。）を $20 \mathrm{mM}$ の $\mathrm{NaHCO}_{3}$ で $\mathrm{pH} 7.4$ とし, $95 \% \mathrm{O}_{2} / 5 \% \mathrm{CO}_{2}$ ガスで $37^{\circ} \mathrm{C}, 1$ 時間バブリングしたものを使用し， 実験中もバブリングを持続させた。

腎皮質スライスは次の手順で作成した。ペントバルビタール（50mg/kg, i.p., PitmanMoore）麻酔下でラットを開腹し，腎動脈分岐部より遠位の腹部大動脈及び腎静脈分岐部より遠位 の下大静脈にそれぞれカニューレ（PE-50, Intramedic，Clay Adams）を挿入，固定し，上腸間 膜動脈を結禁してから腹部大動脈及び下大静脈の血流を腎動静脈起始部より近位側で小拑子で遮断 した。腹部大動脈に挿入したカニューレより氷冷した生食を，下大静脈に挿入したカニューレから の流出液に血液の混入がなくなるまで注入し続け腎内を洗浄した。多くの場合，氷冷した生食の注 入量は $30 \mathrm{ml}$ 程度であった。続いて腎臓を摘出し, 氷冷した Earle バッファーに入れ約1分間冷や した後取り出し, 直ちにカミソリを腎の表面に対して平行に動かしてすばやく厚さ約 $0.5 \mathrm{~mm}$ 重さ 40-50mg の腎皮質スライスを1つの腎蔵につき5つずつ切り出し, 氷冷した Earle バッファー中に 保存した。これらの腎皮質スライスは沪紙にて軽く水分を拭き取った後，5スライスずつ集めて重 量を200-250mgにすばやく調整し，これを1検体とした。ラットの両側の腎蔵から，各々5スライ スずつ切り出し，1匹のラットから2検体を作製した。検体はナイロンメッシュで作製したタモ網に 入れこの中で以下のインキュベーション実験を行った。ラットの, 開腹から腎皮質スライスのイン キュベーション開始までは, 30分以内であった。

B）インキュベーション

重量を測定した5片の腎皮質スライスは，あらかじめ $95 \% \mathrm{O}_{2} / 5 \% \mathrm{CO}_{2}$ ガスでバブリングした Earle バッファー内で, $37^{\circ} \mathrm{C}, 30$ 分間プレインキュベーションを行った。続いて5片のスライスを バッファーより取り出し, 汇紙で軽く水分を拭き取った後, 以下の要領で準備した薬物及び組織抽 出液をあらかじめ溶解した新しいバッファー $10 \mathrm{ml}$ 中に移し, 実験を開始した。各群とも実験開始 後 $20,40,60$ 分でバッファーを $1 \mathrm{ml}$ ずつ採取し，レニン測定までー $35^{\circ} \mathrm{C} て ゙$ 凍結保存した。20分と 40 分ではバッファー採取後直ちに $1 \mathrm{ml}$ の新鮮なバッファーを補充した。各々の薬物又は組織抽出液 について, 各群につき, 3匹のラットの計6個の腎臓から各々5スライスずつ切り出し, $\mathrm{n}=6$ とした。

1) ᄂ-イソプロテレノール

L-イソプロテレノール（日研化学株式会社）を $10 \mathrm{ml}$ の Earle バッファーに溶解し10 $0^{-5} \mathrm{M}$ の濃 度とし, 酸化を防ぐために $100 \mu 1$ の Earle バッファーに溶解した L-アスコルビン酸（和光純薬 工業株式会社）をさらに加え $5 \times 10^{-5} \mathrm{M}$ の濃度とした ${ }^{15)}$ 。対照として, $100 \mu 1$ の Earle バッファー に溶解した L-アルコルビン酸を $10 \mathrm{ml}$ の Earle バッファーに加え $5 \times 10^{-5} \mathrm{M}$ の濃度としたものを 用いた。L-イソプロテレノールを溶解した Earle バッファー及び対照の Earle バッファーの実 験開始時の $\mathrm{pH}$ は, ほぼ7.4で, 実験終了時をで $\mathrm{pH}$ の変化はなかった。 


\section{2）フロセマイド}

フロセマイド（へキストジャパン株式会社）を $10 \mathrm{ml}$ の Earle バッファーに溶解し50 $\mu \mathrm{g} / \mathrm{ml}$ の濃度とした。対照として $10 \mathrm{ml}$ の Earle バッファーを用いた。フロセマイドを溶解した Earle バッファー及び対照の Earle バッファーの実験開始時の $\mathrm{pH}$ は, ほぼ7.4で, 実験終了時まで $\mathrm{pH}$ の変化はなかった。

\section{3） プロスタグランジン $\mathrm{E}_{1}$ 及び $\mathrm{I}_{2}$}

プロスタグランジン $\mathrm{E}_{1}$ 又は $\mathrm{I}_{2}$ (小野薬品工業株式会社) を $10 \mathrm{ml} の$ Earle バッファーに溶解し， 共に $10^{-5} \mathrm{M}$ の濃度とした。対照として $10 \mathrm{ml}$ の Earle バッファーを用いた。プロスタグランジン $\mathrm{E}_{1}$ 又は $\mathrm{I}_{2}$ を溶解した Earle バッファー及び対照の Earle バッファーの実験開始時の $\mathrm{pH}$ は，ほぼ7. 4で，実験終了時まで $\mathrm{pH}$ の変化はなかった。

\section{4）ラット顎下腺抽出液}

ペントバルビタール麻酔下の正常ラットから䫇下腺を摘出 ${ }^{21)}$, 罰下腺を指で圧迫して血液を出来

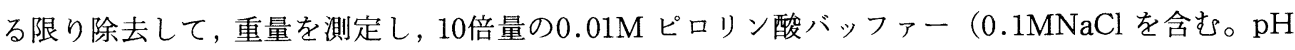
6.5, 以下ピロリン酸バッファーと略す。）とともに氷冷下で Polytron（Kinematika）を用いて3 分間ホモジナイズした後, $4{ }^{\circ} \mathrm{C}, 100,000 \mathrm{G}$ で1時間超遠心し, 得られた上清 $100 \mu 1$ を Earle バッ ファ $-10 \mathrm{ml}$ に添加した。対照としてピロリン酸バッファー100 $\mu 1$ を10ml の Earle バッファー に添加したものを用いた。顎下腺粗抽出液を添加した Earle バッファー及び対照の Earle バッ ファーの実験開始時の $\mathrm{pH}$ は，ほほ77.4で，実験終了時まで $\mathrm{pH}$ の変化はなかった。

\section{C）不活性型レニンのトリプシン活性化法}

採取したサンプル300 $\mu 1$ K trypsin-TPCK (L-1-tosylamide-2-phenylethyl chloromethyl ketone) $30 \mu \mathrm{g}$ (Worthington Diagnostic System Inc.) を加光，氷水中で10分間反応させ，た だちに soybean trypsin inhibitor $30 \mu \mathrm{g}$ (Sigma Chemical Co.) で反応を止めた。

D）レニンの測定

レニンは濃度で測定した。採取したサンプル $100 \mu 1$ Kurakami ら ${ }^{13)}$ の方法で作製した250ng AngI 相当量程度の十分量のラットレニン基質, 及びエタノールに溶解した $1 \%$ の phenylmethylsulfonyl-fluoride $20 \mu 1$ を加光, $37^{\circ} \mathrm{C}, \mathrm{pH} 6.5$ で1時間反応させ, RIA キット（Dainabot）を用 いて生成されたアンギオテンシンIを測定し，これを活性型レニン濃度とした ${ }^{21)}$ 。サンプルをトリ プシンで処理した後に同様の方法で得られた活性型レニン濃度を総レニン濃度とした。総レニン濃 度と活性型レニン濃度の差を不活性型レニン濃度とした。サンプル中のレニン濃度は pgAngI／ $\mathrm{mg}$ 湿重量 $/ \mathrm{h}$ で表した。

E）データ分析

結果は総て mean \pm S.D. で示し， unpaired $\mathrm{t}$-test を用いて $\mathrm{p}<0.05$ を有意とした。

\section{結果}

\section{A）腎皮質スライスからのレニン分泌の経時的変動（図1）}

腎皮質スライスを， $95 \% \mathrm{O}_{2} / 5 \% \mathrm{CO}_{2}$ ガスでバブリングした Earle バッファー内で $37^{\circ} \mathrm{C}, 30$ 分間 インキュベーションした後, 何も加えていない新しいバッファー10 $\mathrm{ml}$ 中に入れ，バブリングを持 続しながら，それからのレニン分泌の経時的変動をみた。活性型レニンも不活性型レニンも，20分， 40分，60分後の值は汪ぼ直線的な上昇を示し，いずれの時間においても，不活性型レニンの值は活 性型レニンの值の数倍であった。 

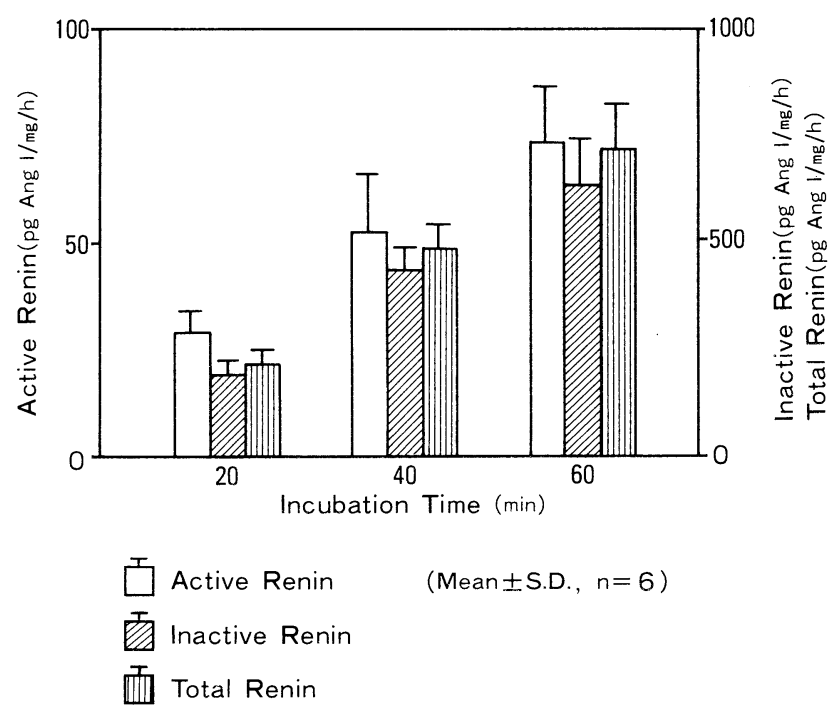

Fig. 1 Time course of renin release from rat renal cortical slices.
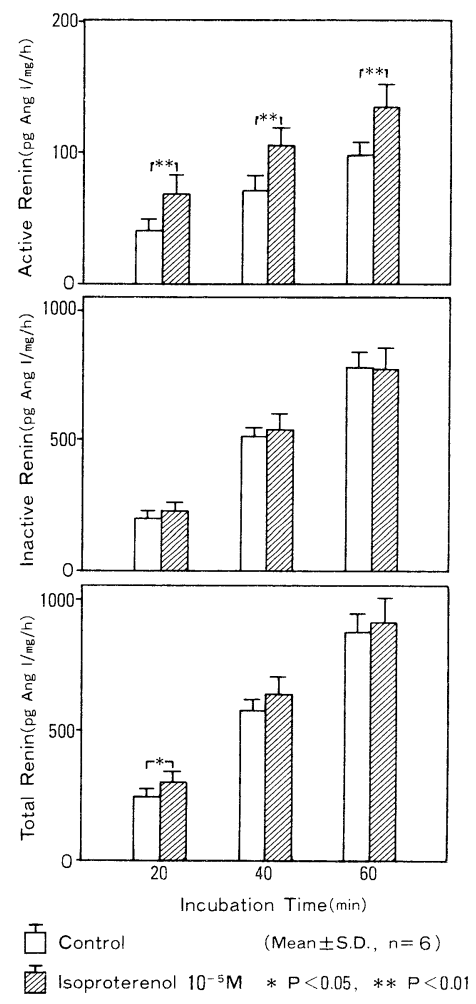

Fig. 2 Effect of isoproterenol on renin release. 


\section{B）腎皮質スライスからのレニン分泌に対する薬物の影響}

\section{1） L-イソプロテレノール（図2）}

L-イソプロテレノール $\left(10^{-5} \mathrm{M}\right)$ を含む Earle バッファー内での腎皮質スライスからのレニン 分泌を検討した。活性型レニンの值は，20分，40分，60分後において，いずれも対照の值に比べて 有意に増加していた（p<0.01）。しかし，不活性型レニンの值は，20分，40分，60分後において， いずれも対照の值に比べて有意な増加を示さなかった。

\section{2）フロセマイド（図3）}

フロセマイド $(50 \mu \mathrm{g} / \mathrm{ml})$ を含む Earle バッファー内での腎皮質スライスからのレニン分泌 を検討した。活性型レニンの值は，20分，40分後には対照の值に比べて有意な増加を示したが $(\mathrm{p}<0.05), 60$ 分後には有意な増加を示さなかった。不活性型レニンの值も，20分，40分後には対 照の值に比べて有意な増加を示したが（ $\mathrm{p}<0.05 ） ， 60$ 分後には有意な増加を示さなかった。

3）プロスタグランジン $E_{1}, I_{2}($ 図4)

プロスタグランジン $\mathrm{E}_{1}$ たは $\mathrm{I}_{2}\left(10^{-5} \mathrm{M}\right)$ を含む Earle バッファー内での腎皮質スライスから のレニン分泌を検討した。活性型レニンの值は，プロスタグランジン $\mathrm{E}_{1}$ を含むバッファーでも， プロスタグランジン $\mathrm{I}_{2}$ を含むバッファーでも，20分，40分，60分後において，いずれも対照の值 に比べて有意な増加を示した $(\mathrm{P}<0.01)$ 。この際，プロスタグランジン $\mathrm{E}_{1}$ と $\mathrm{I}_{2}$ との間では，20分，

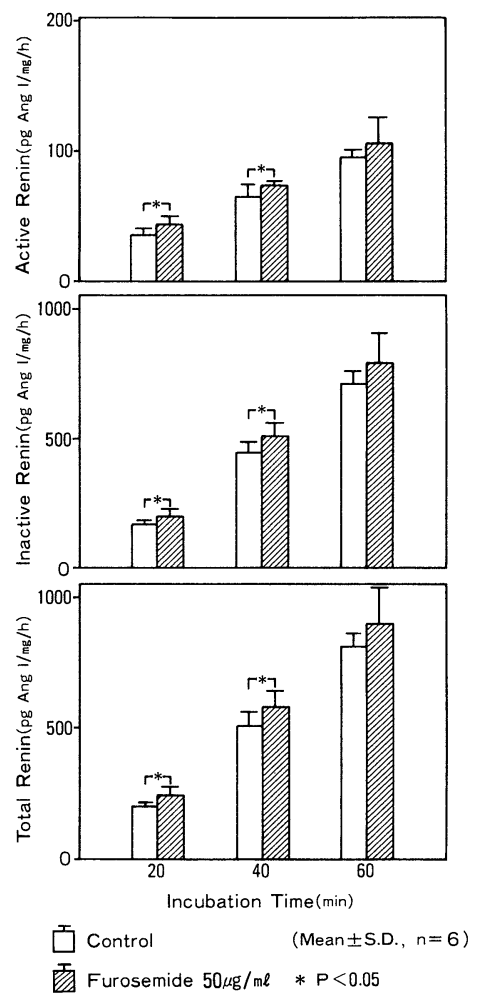

Fig. 3 Effect of furosemide on renin release. 
40分, 60分後のいずれの時間においても, 有意な值の差は認められなかった。不活性型レニンの值 は, プロスタグランジン $\mathrm{E}_{1}$ を含むバッファーでも，プロスタグランジン $\mathrm{I}_{2}$ を含むバッファーでも， 20分，40分，60分後において，いずれも対照の值に比べて有意な減少を示した（p<0.01）。この 際も, プロスタグランジン $\mathrm{E}_{1}$ と $\mathrm{I}_{2}$ との間では, 20 分, 40分, 60分後のいずれの時間においても, 有意な值の差は認められなかった。

4）ラット顎下腺抽出液（図5）

ラット靧下腺抽出液 $(100 \mu \mathrm{l})$ を含む Earle バッファー内での腎皮質スライスからのレニン分 泌を検討した。活性型レニンの值は，20分，40分，60分後において，いずれも対照の值に比べて有 意な值の差は認められなかった。しかし, 不活性型レニンの值は, 20分, 40分, 60分後において, いずれも対照の值に比べて有意な増加を示した（p<0.05）。
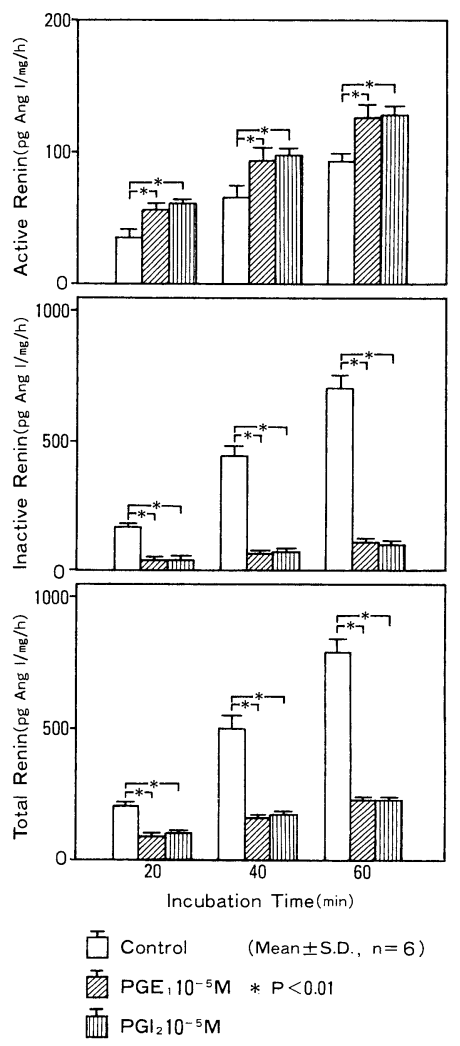

Fig. 4 Effects of prostaglandins on renin release. 


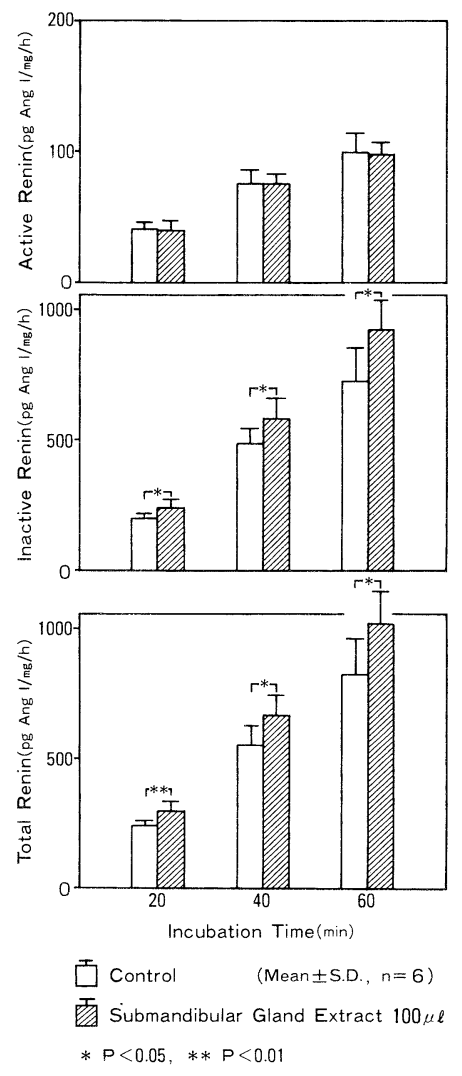

Fig. 5 Effect of submandibular gland extract on renin release.

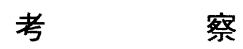

血漿不活性型レニンはヒトやラットを含む哺乳動物に拈いてその存在が認められているものの, その産生部位や分泌機序については未だ不明である ${ }^{2123)}$ 。我々の以前のラットにおける成績では， 両側の腎蔵を摘出すると，血漿活性型レニン（PAR）はすみやかに著減するのに対し，血漿不活 性型レニン (PIR) は増加し，少なくとも腎摘後24時間まで増加が維持されていた。しかし，これ に頸下腺の摘除をも追加すると，腎摘後のPIR の増加は阻止され，腎摘後のPIR の増加に買下 腺が関係している事が示唆された ${ }^{1120)}$ 。顎下腺が PIR 分泌にどのような機序を介して関与してい

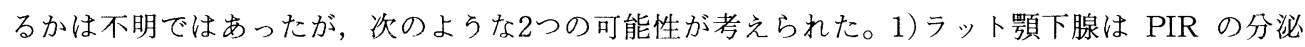
源である。2) ラット顎下腺は PIR の分泌源ではないが他の部位で行われる分泌を調節している。 我々の以前の実験では, ラット顓下腺には活性型，不活性型共にレニンは存在しない事が証明さ れ ${ }^{11)}$, 従って，2）の可能性が示唆された。そこで, 本研究において我々は，2)の可能性を確かめる 為に, ラット腎皮質スライスからの不活性型レニン分泌に対するラット顎下腺抽出液の直接の影響 を調べた。同時に，各種の PAR 分泌刺激剤の活性型レニン，不活性型レニン分泌に対する影響 も検討し，不活性型レニン分泌のメカニズムをあきらかにしょらと試みた。 
ラット ${ }^{1)}, イ^{3)}$, ウサギ7)，ブタ ${ }^{16)}$ ，マウス ${ }^{9)}$ 等の腎皮質スライスを組織培養液中に入れ，そのス ライスから培養液中への活性型レニンの分泌をしらべた実験はいくつか行われている。L-イソプ ロテレノール ${ }^{5141429}$ やイソプレナリン ${ }^{199}$ などの $\beta$ 受容体刺激剤やプロスタグランジン（プロスタグラ ンジン $\mathrm{E}_{1}, \mathrm{I}_{2}^{28}$ など）を培養液に加えると，活性型レニンの分泌が増加する事が認められている。 ウサギ ${ }^{12199}$ ，ブタ ${ }^{15)}$ の腎皮質スライスを用いた実験では，そのスライスから培養液中への不活性型 レニンの分泌も証明されている。 Richards らのウサギの腎皮質スライスを用いた実験 ${ }^{1219)}$ では， 培養液の酸処理（pH2.8で24時間，その後 $\mathrm{pH} 7.5$ で24時間透析する。）により培養液中に分泌さ れた不活性型レニンが活性化される，といら成績が得られている。彼らは，この培養液にイソプレ ナリン ${ }^{19)}$ やロセマイド'12)加えて検討したが，不活性型レニンの分泌に有意な変動は認められな かったという。Okamura らのブタの腎皮質スライスを用いた実験 ${ }^{15)}$ では, トリプシンにより培養 液中に分泌された不活性型レニンが活性化される，といら成績が得られている。この実験において， $\mathrm{DL}$-イソプロテレノール或はプロスタグランジン $\mathrm{E}_{1}$ を培湌液に加えたところ, 我々の結果とは異 なり，不活性型レニンの分泌は增加したという。ラットの腎皮質スライスを用いた実験で不活性型 レニンの分泌を検討したものに Suzuki らの報告 ${ }^{26272}$ があるが，培養液中に不活性型レニンは認め られなかったという。彼らは, 培養液中に分泌された不活性型レニンの活性化を培養液の酸処理に よりおこなっているが，我々が検討したところでは，ラット血漿中にも腎皮質スライスを入れたバッ ファー中にも, 酸処理（pH3.3）により活性化される不活性型レニンは存在しなかった（未発表デー タ）。我々は, 本研究において, トリプシンによる活性化を行っており, この活性化法の相違が我々 と Suzuki らとの結果の差の主因をなすものと思われる。

次に, 我々が実験に使用した各種薬物について, 我々の実験と腎皮質スライスを使った他の報告 における活性型及び不活性型レニンの反応を比較すると以下のようであった。

1) L-イソプロテレノール

L-イソプロテレノール $\left(10^{-5} \mathrm{M}\right)$ の添加では, 活性型レニンの分泌は有意に増加したが, 不活性 型レニンの分泌には有意な変動は認められなかった。ラットの腎皮質スライスを用いたこれまでの 実験報告では, 前述の様に, 活性型レニンの反応のみが検討されているが, L-イソプロテレノー ル $\left(10^{-5} \mathrm{M}\right)$ を用いた場合には, 我々と同じく, 活性型レニンの分泌の有意な増加が報告されてい

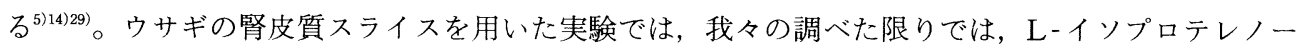
ルの活性型及び不活性型レニンの分泌への影響を検討した報告はなかった。しかし, 同じ $\beta$ 受容体

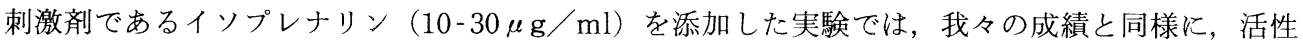
型レニンは有意な増加を示したが，不活性型レニンの有意な変動は認められていない199。また，ブ タの腎皮質スライスを用いた実験では, DL-イソプロテレノール $\left(10^{-7} \mathrm{M}\right)$ の添加で, 活性型のみ ならず不活性型レニンの有意な増加も認められている ${ }^{15)}$ この実験では, 本研究と同様, トリプシ ン活性化法が用いられている。この点, 不活性型レニン分泌に関して, 本研究成績と相違がみられ た理由は不明である。実験動物の種差による影響の可能性も残される。ラットに L-イソプロテレ ノールを静脈内投与すると PAR が有意に増加するとされている2。 今回の我々の実験結果からは, この L-イソプロテレノール静注による PAR の増加は, L-イソプロテレノールが腎の活性型レ ニン分泌細胞を直接的に分泌刺激したため, とも解釈される。また, 以前に, 我々は, ラットを用 いた in vivo での実験において, L-イソプロテレノールは, 買下腺の存在下でのみ PIR を有意 に増加させる事を報告したが2)，今回の我々の実験結果はこれを支持した。 


\section{2) フロセマイド}

フロセマイド $(50 \mu \mathrm{g} / \mathrm{ml})$ の添加では，20分後と40分後においては活性型レニンも不活性型レ ニンも有意に増加したが，60分後においては両者とも有意な変動を示さなかった。60分後に有意差 がなくなった理由の詳細は不明であるが，この経過中に，添加されたフロセマイドがすみやかに不 活化されたために，活性型及び不活性型レニン分泌刺激作用が持続しなかった可能性も残される。 同様の実験がウサギの腎皮質スライスを用いて行われているが, 活性型レニン及び不活性型レニン 共に, フロセマイド (5-40 $\mu \mathrm{g} / \mathrm{ml})$ 添加で有意な変動は認められていない.12)。ラットにフロセマ イドを静脈内投与すると PAR が有意に増加するとされている2)。今回の我々の実験結果からは， このフロセマイド静注による PAR の増加は, フロセマイドが腎の活性型レニン分泌細胞を直接 的に分泌刺激したためではなく，何らかの機序を介して間接的に分泌刺激したため，とも解釈され る。また，以前に，我々は，ラットを用いた in vivo での実験において，フロセマイドは，靧下 腺の存在下でのみ PIR を有意に増加させる事を報告したが2), 今回の我々の実験結果はこれを支 持した。

3）プロスタグランジン

プロスタグランジン $\mathrm{E}_{1}$ 又は $\mathrm{I}_{2}\left(10^{-5} \mathrm{M}\right)$ の添加で, 活性型レニンの分泌はいずれの場合も有意 に増加したが，不活性型レニンの分泌は共に著しく減少した。この際，プロスタグランジン $\mathrm{E}_{1}$ と $\mathrm{I}_{2}$ が腎スライス内の不活性型レニンの活性化を促進した為に活性型レニンの分泌が増加し，その分， 不活性型レニンの分泌が低下したため, という可能性が残されるが，その場合には，活性型レニン と不活性型レニンの和である総レニンの分泌は変動しないと思われる。しかし, 総レニンの值は, プロスタグランジン $\mathrm{E}_{1}$ を含むバッファーでも，プロスタグランジン $\mathrm{I}_{2}$ を含むバッファーでも， 20 分，40分，60分後に抒いて，いずれも，対照の值に比べて著しく減少していた（p<0.01）。これ らは，プロスタグランジン $\mathrm{E}_{1}$ 又は $\mathrm{I}_{2}$ が，腎皮質スライス中の不活性型レニンの活性化を促進した ためと言らよりはむしろ, 不活性型レニンの分泌そのものを抑制した可能性を示唆する。さらに, この事は，これらのプロスタグランジンが，活性型レニン分泌と不活性型レニン分泌に対して，全 く無関係に，活性型レニンに対しては分泌促進的に，不活性型レニンに対しては分泌抑制的に，作 用している可能性をも示唆する。ラットの腎皮質スライスを用いた従来の実験では, プロスタグラ ンジン $\mathrm{E}_{1}$ 又は $\mathrm{I}_{2}\left(10^{-5} \mathrm{M}\right)$ を用いて不活性型レニンの分泌を検討した報告は見当たらないが，活 性型レニン分泌について検討した報告では，我々と同じく，有意な増加が報告されている し，ブタの腎皮質スライスを用いた実験では，プロスタグランジン $\mathrm{E}_{1}(3 \mu \mathrm{g} / \mathrm{ml})$ の添加で活性 型のみならず不活性型レニンの有意な増加が認められたという報告がある ${ }^{15)}$ 。以前に, 我々は, ラッ トにプロスタグランジン $\mathrm{E}_{1}$ 又は $\mathrm{I}_{2}$ を静脈内投与すると，両側靧下腺の摘除の有無に拘わらず， PAR は有意に増加し, PIR は有意に隇少する事を報告したが2), 今回の我々の実験結果もこれに 一致し，この PAR の増加は，プロスタグランジン $\mathrm{E}_{1}$ 又は $\mathrm{I}_{2}$ が腎の活性型レニン分泌細胞を直接 的に分泌刺激したために抗こり, PIR の減少は, プロスタグランジン $\mathrm{E}_{1}$ 又は $\mathrm{I}_{2}$ が不活性型レニン 分泌細胞を直接的に分泌抑制したためにおこる，とも解釈される。

\section{4）ラット顎下腺抽出液}

ラット顎下腺抽出液（100 $\mu 1 ）$ の添加では, 活性型レニンの分泌は有意な変動を示さなかったが, 不活性型レニンの分泌は有意に増加した。我々の調べた限りでは, 腎皮質スライスを用いた他の実 験では，頱下腺の影響を検討したものはない。前述した我々のラットの in vivo での実験結果か 
らも, 靧下腺には不活性型レニンの分泌を促進する何らかの成分があると推定されるが，カリクレ インやトニン6(1024) などの䫑下腺に含まれる血圧に影響を与えるプロテアーゼとの関係は今回の実験 結果からはわからなかった。

今回のラットの腎皮質スライスを用いた実験で, L-イソプロテレノールは, 活性型レニン分泌 を促進したが，不活性型レニン分泌は促進しなかった。フロセマイドは，両者の分泌を一過性に促 進した。一方, プロスタグランジン $\mathrm{E}_{1}$ 又は $\mathrm{I}_{2}$ は, 活性型レニン分泌を促進したが, 不活性型レニ ン分泌は抑制した。また, ラット顎下腺抽出液は, 不活性型レニン分泌を促進したが, 活性型レニ

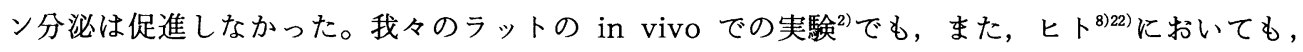
アンギオテンシン I 変換酵素阻害剤のカプトプリルやアンギオテンシンII拮抗剤を投与すると, PAR は有意に増加するが PIR は変動しない。これらの事は, 活性型レニンと不活性型レニンの 分泌がそれぞれ独立して行われている可能性を示唆するものと思われる。

Dzau ら ${ }^{1718)}$ はヒトのレニン遺层子をマウスの線維芽細胞, チャイニーズハムスターの卵巣の細 胞, マウスの下垂体腫瘍の細胞に移しかえ，それらの細胞によるレニンの合成と分泌を調べた。そ の結果，ヒトのレニンの分泌経路には，1）ゴルジ装置より直接分泌される「constitutive pathway」 （以下 $\mathrm{C}$ 経路と略す。）と，2）ゴルジ装置より更に分泌顆粒を介して分泌される「regulated pathway」（以下 R 経路と略す。）の，少なくとも2つの経路があり，不活性型レニンは，C経路 を介して分泌され，活性型レニンは， $\mathrm{R}$ 経路を介して分泌される事が推定された。ラットのレニ ンの分泌も同じ経路で行われているとすれば，L-イソプロテレノールは R 経路を介する分泌の みを促進すると推定される。L-イソプロテレノールのような $\beta$ 受容体刺激剤の作用は $\mathrm{c}$ - AMP を 介すると考光られているので, $\mathrm{R}$ 経路の分泌には c-AMP が関係している可能性がある。更に, ラット靧下腺抽出液は $\mathrm{C}$ 経路を介する分泌のみを促進し, 抽出液中の何らかの成分が $\mathrm{C}$ 経路の 分泌に関係していると推定される。顎下腺を摘出していない正常ラットに L-イソプロテレノール やフロセマイドを投与すると, 類下腺からこの成分が放出され，それが不活性型レニン分泌細胞に 作用し，その分泌を促進させ，その結果，PIR が増加する，と考光る事が可能であろう。また， プロスタグランジン $\mathrm{E}_{1}$ と $\mathrm{I}_{2}$ は, $\mathrm{C}$ 経路の分泌を抑制する一方で, $\mathrm{R}$ 経路の分泌を促進すると思わ れるが，詳しい分泌機序の解明には更に研究が必要である。

結 論

ラット腎皮質スライスからの活性型レニン及び不活性型レニンの分泌について検討し，あわせて， これに対する各種薬物の影響を検討した結果，以下の成績が得られた。

1）L-イソプロテレノールは，ラット腎皮質スライスからの活性型レニン分泌を促進したが，不 活性型レニン分泌は促進しなかった。フロセマイドは, 両者の分泌を一過性に促進した。一方，プ ロスタグランジン $\mathrm{E}_{1}$ 又は $\mathrm{I}_{2}$ は，活性型レニン分泌を促進したが，不活性型レニン分泌は抑制した。 また, ラット䫕下腺抽出液は, 不活性型レニン分泌を促進したが, 活性型レニン分泌は促進しなかっ た。

2）以上から，ラット腎皮質スライスからの活性型レニンと不活性型レニンの分泌は上記各種薬物 に対して互いに無関係に反応する場合があり, 両者の分泌機序は異なっている可能性がある, と推 定された。

3）ラットに㧍ける不活性型レニンの分泌には，䫇下腺に含まれる何らかの物質とプロスタグラン 
ジン $\mathrm{E}_{1}$ と $\mathrm{I}_{2}$ が関与している。前者は促進的に, 後者は抑制的に作用する。

本論文の要旨は第8回国際内分泌学会において発表した。なお, 本研究の一部は, 文部省科学研 究費(63570390)及び，秩父セメント株式会社奨学金によった。

\section{文献}

1) Churchill, P.C., McDonald, F.D. and Churchill, M.C.: Phenytoin stimulates renin secretion from rat kidney slices. J. Pharmacol. Exp. Ther., 211: 615-619, 1979.

2) Dodo, S., Miyazaki, S., Sakanaka, A., Goi, R., Chimori, K. and Miura, K.: In vivo mechanisms of plasma inactive renin release in the rat. 8th international congress of endocrinology (Abstract): 556, $1988 . \quad 3$ 3) Gaál, K., Siklós, J., Mózes, T. and Tóth, G.F.: Effect of papaverine on renin release in dogs in vivo and in vitro. Acta Physiol. Acad. Sci. Hung., 51: 305-314, $1978 . \quad 4$ 4) Hackenthal, E. and Taugner, R.: Hormonal signals and intracellular messengers for renin secretion. Mol. Cell. Endocrinol., 47: 1-12, $1986 . \quad 5)$ Henrich, W.L. and Campbell, W.B.: Relationship between $\mathrm{PG}$ and $\beta$-adrenergic pathways to renin release in rat renal cortical slices. Am. J. Physiol., 247: E343-E348, $1984 . \quad$ 6) Hirata, Y., Tomita, M., Fujita, T. and Ikeda, M.: In vitro secretion of immunoreactive tonin from dispersed rat submandibular gland cells. Hypertension, 8: 883-889, $1986 . \quad 7)$ Lazar, J.D. and Whorton, A.R.: Prostaglandin mediation of potassium effects on renin release. Life Sci., 27: 1327-1333, 1980. 8) Leckie, B.J., McConnell, A., Grant, J., Morton, J.J., Tree, M. and Brown, J.J.: An inactive renin in human plasma. Circ. Res., 40: I-46-I-51, 1977. 9) Lin, C.S., Iwao, H., Puttkammer, S. and Michelakis, A.M.: Prostaglandins and renin release in vitro. Am. J. Physiol., 240: E609-E614, 1981.

10) Maitra, S.R., Rabito, S.F. and Carretero, O.A.: Release of kallikrein and tonin from the rat submandibular gland. Adv. Exp. Med. Biol., 198 Pt A: 247-254, 1986.

11) Miyazaki, S., Sakanaka, A., Chimori, K., Kosaka, J., Goi, R., Dodo, S., Miura, K. and Suzuki, F.: Reno-submandibular axis controls release of extrarenal inactive renin. J. Hypertension, 6: 33-40, 1988. 12) Munday, K.A., Noble, A.R. and Richards, H.K.: Active and inactive renin release from rabbit kidney cortex slices: Effect of sodium concentration and of furosemide. J. Physiol. (Lond.), 328: 421-430, 1982. 13) Murakami, K., Takahashi, S., Suzuki, F., Hirose, S. and Inagami, T.: Intermediate molecular weight renin and renin-binding protein $(\mathrm{s})$ in the hog kidney. Biomed. Res., 1: 392-399, 1980. 14) Naftilan, A.J. and Oparil, S.: The role of calcium in the control of renin release. Hypertension, $4: 670-675,1982$. 15) Okamura, T. and Inagami, T. : Release of active and inactive renin from hog renal cortical slices in vitro. Am. J. Physiol., 246: F765-F771, 1984. 16) Park, C.S., Han, D.S. and Fray, J.C.S. : Calcium in the control of renin secretion: $\mathrm{Ca}^{2+}$ influx as an inhibitory signal. Am . J. Physiol., 240: F70-F74, 1981. 17) Pratt, R.E., Carleton, J.E., Richie, J.P., Heusser, C. and Dzau, V.J.: Human renin biosynthesis and secretion in normal and 
ischemic kidneys. Proc. Natl. Acad. Sci. USA, 84: 7837-7840, 1987.

18) Pratt, R.E., Flynn, J.A., Hobart, P.M., Paul, M. and Dzau, V.J.: Different secretory pathways of renin from mouse cells transfected with the human renin gene. J. Biol. Chem., 263: 3137-3141, 1988. 19) Richards, H.K., Noble, A.R. and Munday, K.A.: Isoprenaline-induced secretion of active and inactive renin in anaesthetized rabbits and by kidney cortical slices. Clin. Sci., 61: 679-684, 1981.

20）坂中昭典, 宮崎青爾, 小坂譫二, 地守研三, 百々修司, 五井麗司, 三浦 清: ラット血墏不活性型レニンと腎一䫇下腺系 の意義. 日内分泌会誌，63：961-977，1987. 21） Sealey, J.E., Atlas, S.A. and Laragh, J.H.: Prorenin and other large molecular weight forms of renin. Endocrine Reviews, 1: 365-391, $1980 . \quad$ 22) Sealey, J.E., Overlack, A., Laragh, J.H., Stumpe, K.O. and Atlas, S.A.: Effect of captopril and aprotinin on inactive renin. J. Clin. Endocrinol. Metab., 53: 626-630, $1981 . \quad 23)$ Sealey, J.E. and Atlas, S.A.: Inactive renin: Speculations concerning its secretion and activation. J. Hypertension, 2 (Suppl. 1): 115-123, $1984 . \quad 24$ ) Seto, S., Rabito, S.F., Maitra, S.R., Wu, J.N. and Carretero, O.A.: Effect of sodium restriction and corticosteroids on glandular kallikrein in plasma and in the submandibular gland. Adv. Exp. Med. Biol., 198 Pt A: 255-263, 1986. 25) Stella, A. and Zanchetti, A.: Control of renal renin release. Kidney Int., 31 (Suppl. 20): S-89-S-94, $1987 . \quad 26$ ) Suzuki, S., Franco-Saenz, R., Tan, S.Y. and Mulrow, P.J. : Direct action of rat urinary kallikrein on rat kidney to release renin. J. Clin. Invest., 66: 757-762, 1980.27 27) Suzuki, S., Franco-Saenz, R., Tan, S.Y. and Mulrow, P.J.: Direct action of kallikrein and other proteases on the renin-angiotensin system. Hypertension, 3 (Suppl. I): I-13-I-17, 1981.

28) Suzuki, S., Franco-Saenz, R., Tan, S.Y. and Mulrow, P.J.: Direct action of prostaglandins on renin release from rat renal cortical slices. Proc. Soc. Exp. Biol. Med., 166: 484-488, 1981. 29) Urban, J.H., Van de Kar, L.D., Schmitt, S.L. and Brownfield, M.S. : In vitro evidence for a blood-borne renin-releasing factor. Life Sci., 37: 1335-1342, 1985.

（受付日：'89. 5.15） 